\title{
Comorbidity of attention deficit hyperactivity disorder with personality disorders in homeless people
}

\author{
Carlos Salavera ${ }^{1,2^{*}}$, José Luis Antoñanzas ${ }^{1,3}$, Juan Carlos Bustamante ${ }^{1,3}$, José Carrón ${ }^{1,2}$, Pablo Usán ${ }^{1,3}$, Pilar Teruel ${ }^{1,3}$, \\ Carmen Bericat 1,5, Lucía Monteagudo 1,2, Soledad Larrosa ${ }^{1,3}$, José M Tricás $5^{2,4}$, Orosia Lucha ${ }^{2,4}$, Raquel Noé1,3, \\ Laurane Jarie ${ }^{1,3}$ and Raquel Cerra ${ }^{1,3}$
}

\begin{abstract}
Background: Attention deficit hyperactivity disorder (ADHD) is a condition that begins in childhood but can continue into adulthood, and may be the cause of many disadaptive behaviors, as in the case of homeless people, who often display a high incidence of personality disorders. The goal of this study is to analyze the comorbidity of ADHD with axis II disorders in a Spanish homeless population.

Results: The outcomes show high comorbidity between these two kinds of disorders, and that the prevalence of axis II disorders is higher among people with ADHD than among the general population.

Conclusions: From these results we can draw the conclusion that in homeless people ADHD in childhood continues into adulthood, when it is very often observed together with personality disorders. Finally, the implications of this study both for clinical practice and for future lines of research are discussed.
\end{abstract}

Keywords: Hyperactivity, Personality disorders, Comorbidity

\section{Background}

In recent years (2005-2012) the homeless population has increased $132 \%$ in Spain and died in our country a homeless person every five days [1]. Last data reported that more than 22.000 people in homelessness situation were treated in health centers [1]. Currently homelessness is on the increase due to high levels of unemployment and lack of job opportunities for young people. This situation gives rise to extremely high rates of unemployment amongst people aged between 25 and 35, the percentage of unemployment in this segment of the population being significantly higher than that of the general population. The homeless are one of the most vulnerable and disadvantaged groups in society, and in Western Europe and North America alone it is estimated that more than one million people are without homes. These people may take

\footnotetext{
* Correspondence: salavera@unizar.es

'OPIICS Research Group, University of Zaragoza, C/Domingo Miral s/n, 50009

Zaragoza, Spain

${ }^{2}$ Faculty of Health Sciences, University of Zaragoza, C/Domingo Miral s/n,

50009 Zaragoza, Spain

Full list of author information is available at the end of the article
}

refuge temporarily in shelters, although the economic crisis has led to a higher number living in the city streets themselves. They are associated with traumatic ruptures and economic, family and social problems, as well as a low quality of life and high rates of physical and psychic diseases. They suffer obvious mental deterioration as a result of living in the streets, and this is considered the highest level of social exclusion in a modern society [2]. A number of studies have found higher rates of serious mental disorders in homeless people [3]. The most common mental disorders are psychosis, drug dependence, depression and personality disorders.

Attention deficit hyperactivity disorder (ADHD) is a development disorder with its origin in childhood but which can persist in adulthood $[4,5]$. The functional anomalies associated with ADHD include poor work and school performance [6].

It is estimated that about $3-5 \%$ of children and nearly $4 \%$ of adults present ADHD [7,8]. A meta-analysis of follow-up studies concluded that in up to $65 \%$ of children with ADHD, symptoms and anomalies can persist into 
adulthood [9]. To diagnose ADHD in adults we need to determine that the adult suffered ADHD in childhood and meets the current criteria for adult ADHD. This clinical profile might include inattentive symptoms, hyperactiveimpulsive symptoms, altered executive functioning, and emotional and behavioral dysregulation $[10,11]$. Low frustration tolerance, emotional lability and difficulty managing strong emotions are presented in this population [12]. Adults with ADHD show a high rate of psychiatric comorbidity with mood and anxiety disorders, substance abuse, and personality disorders [13-17].

Symptoms of ADHD in childhood are consistent with those showed by homeless people, who display social, emotional and personal instabilities which influence both their diagnosis and prognosis. Moreover, the prevalence of organic and mental disorders is much higher in this population than in the population at large $[18,19]$. In spite of this, the presentation of ADHD in childhood and adulthood in the homeless population has not been extensively studied, and this may affect its prognosis. The evaluation of its comorbidity is very important in this case, due to the high rates of personality disorders present in this particular population [20].

The goal of this study is to analyze the comorbidity of ADHD and personality disorders in homeless people.

\section{Methods}

\section{Subjects}

Most homeless people in Spain receive assistance from various public-funded municipal bodies, and it is very difficult to determine the percentage of this population relative to the general population. Our study was carried out in a city of 700.000 inhabitants. The sample consisted of homeless people $(\mathrm{N}=196)$ taking part in a process of psychosocial insertion at a special centre of Zaragoza (Spain), where they received psychological and social support and occupational training. The participants in the study were selected from among 203 people involved in the insertion process and were chosen according to the following criteria: a) condition of homelessness; b) having stayed for more than two months in the centre; c) voluntary participation in the study; and d) a long enough stay for the completion of the study. All the participants provided written informed consent prior to participating in the study. This study was approved by the ethics committee of Department of Psychology and Sociology at the University of Zaragoza, which complied with the ethical requirements of the Declaration of Helsinki.

Given the aim of our study a clinical psychologist carried out the assessment process to evaluate the ADHDrelated clinical profile of each participant, where they selfreported the existence of ADHD in childhood or a current profile of ADHD in adulthood [10].

\section{Assessment measurements}

- Initial assessment interview. To begin with, a structured clinical individual interview was conducted in order to establish a diagnosis. At this interview the salient data were collected: age, marital status, educational level, age at which the subject began a transient life, the causes that led her/him to this kind of life, incidence of alcohol or drug abuse.

- MCMI II. Millon Multiaxial Clinical Inventory II [21]. This is composed of 175 true/false statements that reportedly take 25-30 minutes to answer. It provides 10 basic personality scales, three pathological personality scales, six moderately severe clinical syndrome scales and three severe clinical syndrome scales (Cronbach's alpha $=0.86$ ).

- ASRS. Adult Self-Report Scale Version 1.1 (ASRS v.1.1) [22]. This is an 18-item questionnaire for measuring current ADHD symptoms in adults. Each item is a question about symptoms presentation in the 6 months prior to the assessment, answered using a 5-option Likert scale (Cronbach's alpha $=0.88$ ).

- WURS. Wender-Utah Rating Scale [23]. For assessment of ADHD in childhood; a 25-item self-applied questionnaire. The subject answers questions about her/ his behaviour in childhood using a 4-option Likert scale (Cronbach's alpha $=0.90)$.

\section{Procedure}

The participants' profile up to the present was analyzed using an initial structured interview, reflecting mainly sociodemographic data and personal history as a homeless person. The statistical analysis of the data was carried out using the statistical program SPSS version 21.0. A descriptive analysis was performed (maxima, minima, averages and standard deviation) for each of the variables. In all cases the significance level used was 5\%. Crossed variables and bilateral correlation analyses were also carried out. All the tests were applied and corrected by the clinical psychologist in charge of the research.

\section{Results}

\section{Sociodemographic variables}

This section evidences the high proportion of young homeless people included in the integration process (Table 1). $64.79 \%$ of the subjects in the process were younger than forty. The most frequent marital status of the subjects was single, at $57.14 \%(\mathrm{n}=112)$, while $39.78 \%$ $(\mathrm{n}=78)$ were separated or divorced. In schooling, high early school dropout rates were detected. $37.34 \%(n=73)$ of the sample obtained only the high school certificate (up to age 14$)$, and only $18.36 \%(n=36)$ continued studying 
Table 1 Sociodemographic features of the sample $(\mathrm{N}=196)$

\begin{tabular}{|c|c|c|c|}
\hline & & Frequency & Percentage \\
\hline \multirow[t]{4}{*}{ Age } & $<30$ & 59 & $30.10 \%$ \\
\hline & $30-39$ & 68 & $34.69 \%$ \\
\hline & $40-49$ & 57 & $29.08 \%$ \\
\hline & $>50$ & 12 & $6.12 \%$ \\
\hline \multirow[t]{5}{*}{ Marital status } & Single & 112 & $57.14 \%$ \\
\hline & Married & 3 & $1.53 \%$ \\
\hline & Divorced & 35 & $17.85 \%$ \\
\hline & Separated & 43 & $21.93 \%$ \\
\hline & De facto union & 3 & $1.53 \%$ \\
\hline \multirow[t]{5}{*}{ Schooling } & Without schooling & 3 & $2.04 \%$ \\
\hline & High School Certificate & 73 & $37.24 \%$ \\
\hline & Primary School & 84 & $42.85 \%$ \\
\hline & Professional School & 23 & $11.73 \%$ \\
\hline & Pre-University Studies & 13 & $6.63 \%$ \\
\hline \multirow{4}{*}{$\begin{array}{l}\text { Age when started } \\
\text { living in the street }\end{array}$} & $<20$ & 83 & $42.34 \%$ \\
\hline & 20 a 29 & 69 & $35.20 \%$ \\
\hline & 30 a 39 & 40 & $20.40 \%$ \\
\hline & 40 a 49 & 4 & $2.04 \%$ \\
\hline \multirow{6}{*}{$\begin{array}{l}\text { Reasons for living } \\
\text { in the street }\end{array}$} & Divorce & 31 & $15.81 \%$ \\
\hline & $\begin{array}{l}\text { Problems with family } \\
\text { of origin }\end{array}$ & 56 & $28.57 \%$ \\
\hline & Work problems & 21 & $10.71 \%$ \\
\hline & Addictions & 63 & $32.14 \%$ \\
\hline & Psychological problems & 23 & $11.73 \%$ \\
\hline & Other & 2 & $1.02 \%$ \\
\hline
\end{tabular}

after completing compulsory education. The commonly early beginning of the transient life was also observed, $42.34 \%$ of the subjects having embarked on this kind of life even before the age of 20 . The reasons that led these people to their life in the streets were mainly problems with their family of origin (28.57\%), addictions $(32.14 \%)$ and divorce (15.81\%).

\section{Personality variables}

According to the results obtained from the Millon Multiaxial Clinical Inventory (MCMI-II), 154 of the subjects $(78.57 \%$ of the sample) showed one or more personality disorders (Table 2). Antisocial (26.4\%; $\mathrm{n}=37$ ), dependency $(22.1 \% ; n=31)$, compulsive $(26.4 \% ; n=37)$ and schizoid $(21.4 \% ; \mathrm{n}=30)$ disorders obtained the highest scores, using a Base Rate $(B R)>84$ following more conservative criteria [24]. We should highlight that some subjects' test results showed that they may have one or more high-scoring subscale.
Table 2 MCMI II scores $(\mathbf{N}=196)$

\begin{tabular}{lcccc}
\hline & Minimum & Maximum & Average & S.D. \\
\hline Schizoid & 0 & 116 & 58.67 & 28.23 \\
Phobic & 1 & 103 & 50.37 & 29.69 \\
Dependent & 0 & 108 & 55.29 & 30.6 \\
Histrionic & 5 & 103 & 52.50 & 25.62 \\
Narcissistic & 0 & 106 & 56.59 & 25.67 \\
Antisocial & 0 & 124 & 66.71 & 28.93 \\
Aggressive & 2 & 121 & 55.63 & 28.86 \\
Compulsive & 5 & 118 & 68.06 & 27.49 \\
Passive & 0 & 103 & 42.34 & 26.3 \\
Self-destructive & 2 & 109 & 50.91 & 25.92 \\
Schizotypal & 3 & 117 & 56.86 & 27.16 \\
Limit & 0 & 116 & 48.59 & 27.26 \\
Paranoid & 4 & 118 & 61.31 & 25.59 \\
\hline
\end{tabular}

The number of personality disorders present in each subject was analyzed. Some subjects receiving the homeless insertion treatment showed no personality disorders (16.42\% of cases; $n=23)$, while others in the sample displayed one $(22.14 \% ; n=31)$, two $(12.14 \%$; $n=17)$ or even three or more $(49.28 \%$; $n=69)$.

\section{ADHD variables}

Results showed that $14.28 \%$ of the sample $(n=28)$ could be diagnosed as suffering from ADHD in childhood, whereas $8.16 \%$ of the participants $(n=16)$ would have a current diagnosis of ADHD. This would imply that 57.14\% of the subjects would maintain this diagnosis throughout their lives.

Furthermore, comorbidity of personality disorders and ADHD was studied (Table 3), taking into account both past (WURS) and current (ASRS) diagnoses of ADHD. Whether a diagnosis of ADHD in childhood could determine in any way a personality disorder in adulthood was also analysed. In this sense, we found an association between personality disorders like aggressive, compulsive, self-defeating, borderline and paranoid disorders and the past ADHD diagnoses in childhood. Likewise, we found a significant effect in the association between those personality disorders and current ADHD in adulthood.

Finally, we sought to determine whether suffering from ADHD could lead to the presentation of a personality disorder in adulthood (Table 4). The outcomes in this section indicated a higher correlation between ADHD and personality disorders as the age of the subjects increased.

\section{Discussion}

Previous studies show a $4 \%$ occurrence of ADHD in adults, although some authors consider that this disorder is underdiagnosed and consequently wrongly treated [25]. 
Table 3 Comorbidity of ADHD and personality disorders

\begin{tabular}{|c|c|c|c|c|c|c|c|}
\hline & & & WURS & & & ASRS & \\
\hline & & Absence & Presence & $x^{2}$ & Absence & Presence & $x^{2}$ \\
\hline Schizoid & Absence & 131 & 23 & 68.67 & 138 & 16 & $172.02^{* * *}$ \\
\hline & Presence & 33 & 9 & & 36 & 6 & \\
\hline Phobic & Absence & 141 & 23 & 60.27 & 155 & 9 & $133.63^{* * *}$ \\
\hline & Presence & 23 & 9 & & 19 & 13 & \\
\hline Dependent & Absence & 124 & 28 & 69,59 & 133 & 19 & $153.34^{* * *}$ \\
\hline & Presence & 40 & 4 & & 41 & 3 & \\
\hline Histrionic & Absence & 149 & 26 & 69.39 & 156 & 19 & $183.45^{* * *}$ \\
\hline & Presence & 15 & 6 & & 18 & 3 & \\
\hline Narcissistic & Absence & 147 & 29 & 53.67 & 160 & 16 & $98.0^{* * *}$ \\
\hline & Presence & 17 & 3 & & 14 & 6 & \\
\hline Antisocial & Absence & 124 & 17 & 60.49 & 141 & 0 & $168.40^{* * *}$ \\
\hline & Presence & 40 & 15 & & 33 & 22 & \\
\hline Aggressive & Absence & 143 & 22 & $78.25^{* *}$ & 156 & 9 & $188.47^{* * *}$ \\
\hline & Presence & 21 & 10 & & 18 & 13 & \\
\hline Compulsive & Absence & 126 & 16 & $75.91^{*}$ & 126 & 16 & $154.71^{* * *}$ \\
\hline & Presence & 48 & 6 & & 48 & 6 & \\
\hline Passive & Absence & 157 & 25 & 69.13 & 170 & 12 & $173.42^{* * *}$ \\
\hline & Presence & 7 & 7 & & 4 & 10 & \\
\hline Self-destructive & Absence & 151 & 25 & $66.65^{*}$ & 161 & 15 & $169.08^{* * *}$ \\
\hline & Presence & 13 & 7 & & 13 & 7 & \\
\hline Schizotypal & Absence & 135 & 23 & 64.29 & 149 & 9 & $145.07^{* * *}$ \\
\hline & Presence & 29 & 9 & & 25 & 13 & \\
\hline Limit & Absence & 154 & 20 & $73.26^{*}$ & 174 & 0 & $196.00^{* * *}$ \\
\hline & Presence & 10 & 12 & & 0 & 22 & \\
\hline Paranoid & Absence & 139 & 25 & $69.02^{*}$ & 151 & 13 & $158.72^{* * *}$ \\
\hline & Presence & 25 & 7 & & 23 & 9 & \\
\hline
\end{tabular}

${ }^{*} \mathrm{p}<.05 ;{ }^{* *} \mathrm{p}<.01 ;{ }^{* * *} \mathrm{p}<0.01$.

In common with existing studies $[9,13,26]$, in the present study it was found that nearly two out of every three subjects diagnosed in childhood were still diagnose $d$ with this disorder on reaching adulthood. It could be affirmed that the comorbidity of ADHD in adults is more the norm than the exception [27], and that this factor may lead to diagnostic and therapeutic failure.

In our research strong correlations between the outcomes obtained both with ASRS and MCMI-II were observed, although the first measures axis I disorders such as inattention, hyperactivity and impulsivity [28], and the second axis II disorders such as complex behaviour patterns [29]. This would mean that the ASRS measures symptoms common to personality disorders, especially to the disruptive personality. In the case of the results obtained from the WURS questionnaire, their correlations with the MCMI-II were lower than in the case of MCMI-II with
ASRS. This would mean that as age increases, even when the incidence of personality disorders decreases, the comorbidity of ADHD and personality disorders increases [30]. It remains to clarify whether ADHD acts as a moderator or mediator in the subsequent presentation of personality disorders, along the lines suggested [31]; however both disorders fit into a pattern of comorbidity [20].

Not every personality disorder showed a positive correlation with ADHD. The correlations observed with both the dependent and the compulsive disorders were negative. The correlation was stronger with the more severe disorders, both impulsive spectrum disorders with "fight response" (antisocial, negativistic and limit) and schizophreniform spectrum disorders with "flight response" (schizotypal, self-destructive and avoidant). These results coincide with those obtained in previous studies [32]. 
Table 4 Correlation between ADHD and personality disorders

\begin{tabular}{lcc}
\hline & WURS & ASRS \\
\hline Schizoid & .02 & -.01 \\
Phobic & $.20^{* *}$ & $.39^{* *}$ \\
Dependent & $-.15^{*}$ & $-.22^{* *}$ \\
Histrionic & .06 & .05 \\
Narcissistic & .08 & $.26^{* *}$ \\
Antisocial & $.21^{* *}$ & $.46^{* *}$ \\
Aggressive & $.15^{*}$ & $.47^{* *}$ \\
Compulsive & $-.17^{*}$ & -.10 \\
Passive & $.18^{*}$ & $.43^{* *}$ \\
Self-destructive & .1 & $.41^{* *}$ \\
Schizotypal & $.19^{* *}$ & $.38^{* *}$ \\
Limit & $.29^{* *}$ & $.68^{* *}$ \\
Paranoid & .04 & $.34^{* *}$ \\
\hline
\end{tabular}

**The correlation is significant at a level of 0.01 (bilateral).

*The correlation is significant at a level of 0.05 (bilateral).

\section{Conclusions}

According to the results of this study where the study population demonstrate an early beginning of transient living, the homeless people examined displayed more significant psychopathological symptoms, both in ADHD and the personality disorders, than the general population, in addition to the correlation between psychological and personality disorders [33,34]. Homeless people show difficulties in achieving goals and maintaining an adequate level of performance at work, as well as in developing satisfactory interpersonal relationship [35]. Our results showed how difficult is for this population to establish and maintain a steady relationship. These difficulties are probably connected with the academic and labour problems displayed by people with ADHD, and may demonstrate the connection between both pathologies.

These findings have useful clinical implications due to determine a better comprehension of specific clinical profile in homeless people for setting adjusted intervention programs. However, the sample size was relatively small from a statistical perspective. Moreover, other limitation could be related with the fact that we did not include a control group in the sampling process. This methodological approach could give more consistency to the empirical evidence showed in our study. Future studies will overcome these limitations, and are required in order to identify the specific profiles and evolution of attention deficit hyperactivity and personality disorders in homeless population.

In future lines of investigation, the presence of other clinical manifestations in conjunction with ADHD should be studied, since this causes confusion in the therapeutic approach and makes treatment of these patients more difficult. Furthermore, it is possible that the comorbidity of ADHD with other disorders has different clinical subtypes, phenotypes or other phenotype expressions that should be studied to achieve a better understanding of this pathology.

\section{Abbreviations}

ADHD: Attention deficit hiperactivity disorder; ASRS: Adult self-report scale;

INE: Institute national of stadistical; MCMI II: Millon multiaxial clinical inventory II; OPIICS: Observatory for investigation and innovation social sciences; WURS: Wender-Utah rating scale.

\section{Competing interests}

The authors declare that they have no competing interests.

\section{Authors' contributions}

CS, JLA, JCB, PT, JMT \& OL have made substantial contributions to conception and design, or acquisition of data, or analysis and interpretation of data; $C B, J C, S L, L M P U, R N, L J \& R C$ have been involved in drafting the manuscript or revising it critically for important intellectual content. All authors read and approved the final manuscript.

\section{Acknowledgement}

This study was performed by Research Group OPIICS, University of Zaragoza (Zaragoza, Spain) and supported by research funds provided by the Department of Science and Technology of the Government of Aragón (Spain), and the European Social Fund. We wish to acknowledge the extensive and continuous help of all patients, without whom the present registry would have not been possible.

\section{Author details}

'OPIICS Research Group, University of Zaragoza, C/Domingo Miral s/n, 50009 Zaragoza, Spain. ${ }^{2}$ Faculty of Health Sciences, University of Zaragoza, C/Domingo Miral s/n, 50009 Zaragoza, Spain. ${ }^{3}$ Faculty of Education, University of Zaragoza, C/Pedro Cerbuna, 12, 50009 Zaragoza, Spain. ${ }^{4}$ Physiotherapy Research Unit, Faculty of Health Sciences, University of Zaragoza, C/Domingo Miral s/n, 50009 Zaragoza, Spain. ${ }^{5}$ Faculty of Social Sciences and Work, University of Zaragoza, C/Violante de Hungría s/n, 50009 Zaragoza, Spain.

Received: 2 October 2014 Accepted: 31 October 2014

Published: 16 December 2014

\section{References}

1. Instituto Nacional de Estadística: Encuesta a las personas sin hogar. Madrid: INE; 2012.

2. Folsom DF, Hawthorne W, Lindamer L, Gilmer T, Bailey A, Golshan S, García P, Unützer J, Hough R, Jeste D: Prevalence and risk factors for homelessness and utilization of mental health services among 10,340 patients with serious mental illness in a large public mental health system. Am J Psychiatry 2005, 162:370-376.

3. Fazel S, Khosla V, Doll H, Geddes J: The prevalence of mental disorders among the homeless in western countries: systematic review and meta-regression analysis. PLoS Med 2008, 5:e225.

4. Biederman J, Faraone SV, Mick E: The age-dependent decline of attention deficit hyperactivity disorder: a meta-analysis of follow-up studies. Psychol Med 2006, 36:159-165.

5. Kessler RC, Adler L, Barkley R, Biederman J, Conners CK, Demler O, Faraone SV, Greenhill LL, Howes MJ, Secnik K, Spencer T, Ustun TB, Walters EE, Zaslavsky AM: The prevalence and correlates of adult ADHD in the United States: results from the national comorbidity survey replication. Am J Psychiatry 2006, 163:716-727.

6. Daley D: Attention deficit hyperactivity disorder: a review of the essential facts. Child Care Health Dev 2006, 32:193-204.

7. Fayyad J, De Graaf R, Kessler R, Alonso J, Angermeyer M, Demyttenaere K, De Girolamo G, Haro JM, Karam EG, Lara C, Lépine JP, Ormel J, Posada-Villa J, Zaslavsky AM, Jin R: Cross-national prevalence and correlates of adult attention-deficit hyperactivity disorder. Br J Psychiatry 2007, 190:402-409.

8. Polanczyk P, Rohde LA: Epidemiology of attention deficit/hyperactivity disorder across the lifespan. Curr Opin Psychiatry 2007, 20:386-392. 
9. Biederman J, Faraone SV, Spencer T, Wilens T, Norman D, Lapey KA, Mick E, Lehman BK, Doyle A: Patterns of psychiatric comorbidity, cognition, and psychosocial functioning in adults with ADHD. Am J Psychiatry 1993, 150:1792-1798.

10. Dunne EM, Hearn LE, Rose JJ, Latimer WW: ADHD as a risk factor for early onset and heightened adult problem severity of illicit substance use: an accelerate gateway model. Addict Behav 2014, 39:1755-1758.

11. Vidal R, Valero S, Nogueira M, Palomar G, Corrales M, Richarte V, Bosch R, Gómez-Barros N, Corominas M, Casas M, Ramos-Quiroga JA: Emotional lability: the discriminative value in the diagnosis of attention deficit/ hyperactivity disorder in adults. Compr Psychiatry 2014, 55(7):1712-1719.

12. Nigg JT, Casey BJ: An integrative theory of attention-deficit/hyperactivity disorder based on the cognitive and affective neurosciences. Dev Psychopathol 2005, 17:785-806.

13. Craig WS: Adult attention deficit hyperactivity disorder. J Mens Health 2011, 8(4):299-305.

14. Mannuzza S, Klein RG, Bessler A: Adult psychiatric status of hyperactive boys grown up. Am J Psychiatry 1998, 155:493-498.

15. Scott W: Adult attention deficit hyperactivity disorder. J Mens Health 2011, 8(4):299-305.

16. Weiss G, Hechtman L, Milroy T, Perlman T: Psychiatric status of hyperactives as adults: a controlled prospective 15-year follow-up of 63 hyperactive children. J Am Acad Child Psychiatry 1985, 24:211-220.

17. Zwi M, York A: Attention deficit hyperactivity disorder in adults; validity unknown. Adv Psychiatr Treat 2004, 10:248-269.

18. Thompson RG, Hasin D: Psychiatric disorders and treatment among newly homeless young adults with histories of foster care. Psychiatr Serv 2012, 63(9):906-912

19. Vágnerová $M M$, Csémy L, Marek J: Personality characteristics of young homeless. Psychiatrie (Prague) 2012, 16(1):8-13.

20. Charlson ME, Pompei P, Ales KA, Mackenzie CR: A new method of classifying prognostic comorbidity in longitudinal studies: development and validation. J Chronic Dis 1987, 40(5):373-383.

21. Millon T: MCMI-II. Inventario Clínico Multiaxial de Millon II (manual). Madrid: TEA Ediciones; 1997.

22. Adler LA, Spencer T, Faraone SV, Kessler RC, Howes MJ, Biederman J, Secnik K: Validity of pilot adult ADHD Self-Report Scale (ASRS) to rate adult ADHD symptoms. Ann Clin Psychiatry 2006, 18(3):145-148.

23. Ward MF, Wender PH, Reimherr FW: The Wender Utah Rating Scale: an aid in the retrospective diagnosis of childhood attention deficit hyperactivity disorder. Am J Psychiatry 1993, 150:885-890.

24. Salavera C, Puyuelo M, Tricás JM, Lucha O: Comorbilidad en trastornos de personalidad: estudio en personas sin hogar. Univ Psychol 2010, 9(2):457-467.

25. Ramos-Quiroga JA, Bosch-Munsó R, Castells-Cervelló X, Nogueira-Morais M, García-Giménez E, Casas-Brugué M: Trastorno por déficit de atención con hiperactividad en adultos: caracterización clínica y terapéutica. Rev Neurol 2006, 42(10):600-606.

26. Polanczyk G, De Lima MS, Horta BL, Biederman J, Rohde LA: The worldwide prevalence of ADHD: A systematic review and metaregression analysis. Am J Psychiatry 2007, 164(6):942-948.

27. Sobanski E: Psychiatric comorbidity in adults with attention-deficit/ hyperactivity disorder (ADHD). Eur Arch Psychiatry Clin Neurosci 2006, 256(Suppl 1):26-31.

28. Kooij SJ, Bejerot S, Blackwell A, Caci H, Casas-Brugue M, Carpentier PJ, Edvinsson D, Fayyad J, Foeken K, Fitzgerald M, Gaillac V, Ginsberg Y, Henry C, Krause J, Lensing MB, Manor I, Niederhofer H, Nunes-Filipe C, Ohlmeier MD, Oswald P, Pallanti S, Pehlivanidis A, Ramos-Quiroga JA, Rastam M, Ryffel-Rawak D, Stes S, Asherson P: European consensus statement on diagnosis and treatment of adult ADHD: the European network adult ADHD. BMC Psychiatry 2010, 10:67.

29. Sánchez G, Jiménez-Gómez F, Ávila A, Merino-Barragán V: Psicopatología y fiabilidad: un análisis comparativo de las escalas de validez entre MCMI-II y MMPI-2. Rev Iberoam Diagn Ev 1999, 11:115-125.

30. Takeda T, Ambrosini PJ, deBerardinis R, Elia J: What can ADHD without comorbidity teach us about comorbidity? Res Dev Disabil 2012, 33(2):419-425

31. Baron RM, Kenny DA: The moderator-mediator variable distinction in social psychological research. Conceptual, strategic, and statistical considerations. J Pers Soc Psychol 1986, 51(6):1173-1182.
32. Miller TW, Nigg JT, Faraone SV: Axis I and II comorbidity in adults with ADHD. J Abnorm Psychol 2007, 116(3):519-528.

33. Millon T, Davis RD: Trastornos de la personalidad. Más allá del DSM-IV. Barcelona: Masson; 1998.

34. Rigazzio JM: Psicopatía, agresividad y trastorno antisocial de la personalidad en sujetos homicidas. Rev Iberoam Diagn Ev 2006, 22(2):111-131.

35. Salavera C, Tricás JM, Lucha O: Personality disorders and psychosocial problems in a group of participants to therapeutic processes for people with severe social disabilities. BMC Psychiatry 2011, 11:192

doi:10.1186/1756-0500-7-916

Cite this article as: Salavera et al:: Comorbidity of attention deficit hyperactivity disorder with personality disorders in homeless people. BMC Research Notes 2014 7:916.

\section{Submit your next manuscript to BioMed Central and take full advantage of:}

- Convenient online submission

- Thorough peer review

- No space constraints or color figure charges

- Immediate publication on acceptance

- Inclusion in PubMed, CAS, Scopus and Google Scholar

- Research which is freely available for redistribution 